\title{
OBITUARY
}

As we go to press, we have learned of the death of Professor James S. Coleman on April 20, 1985. He was founding Director of the African Studies Center on this Campus and served currently as the Chair of the International Studies and Overseas Programs and Professor of Political Science. He was also the author of numerous books and studies of African political development and comparative political systems, several of which were seminal to scholars in the field. He served as President of the African Studies Association in 1963, and strongly supported the transfer of the secretariat to UCLA in 1980. He was the central figure in International Studies at UCLA, and intellectual leader in Political Science, and a giant in African Studies in this country and throughout the world. His friends, admirers, colleagues and students are legion, for he was also a gentleman in the old fashioned meaning of the word as a thoughtful and noble person. There can be only very few people of his kind in any generation. His loss is felt keenly.

\section{ANNUAL MEETING}

The Twenty-Eighth Annual Meeting of the African Studies Association will be held jointly with the Middle East Studies Association in New Orleans, Louisiana, at the Hyatt-Regency Hotel from Saturday, November 23, to Tuesday, November 26, 1985. ASA Program chair is Professor Edmond J. Keller, Department of Political Science, University of California, Santa Barbara, CA 93106, (805) 961-4719. A series of joint panels related to the common scholarly concerns of Africa and the Middle East are being scheduled, as well as papers and panels on all aspects of African Studies from every discipline in the arts, humanities and sciences. Pre-Registrations will be accepted through November 8, 1985, and no refunds can be made after that date. Pre-Registration fees are: Sustaining/Student/Retired/ Unemployed Members: $\$ 12.50$; Regular Members: $\$ 25.00$; Student/Retired/Unemployed Non-Members: $\$ 15.00$; Non-Member Professionals: $\$ 30.00$. Registration fees paid at the Annual Meeting will be slightly higher. Non-members who have not been members of the ASA within the past five years may pay a combined membership/registration fee of $\$ 25.00$ for students or $\$ 50.00$ for Professionals.

\section{ASA BOARD OF DIRECTORS 1985}

Officers

President: Robert J. Cummings (Howard University)

Vice-President: Gerald Bender (University of Southern California)

Past-President: Laura Bohannan (University of Illinois, Chicago Circle)

Retiring in 1987

Edna Bay (Emory University)

Abena Busia (Rutgers University)

Mark DeLancey (University of South Carolina)

Retiring in 1986

Richard Joseph (Dartmouth College)

Carol B. Thompson (University of Southern California) 